\title{
Spatial and Temporal Comparisons of Benthic Composition at Necker Island, Northwestern Hawaiian Islands ${ }^{1}$
}

\author{
Stephanie A. Schopmeyer, ${ }^{2,3}$ Peter S. Vroom, ${ }^{2}$ and fean C. Kenyon ${ }^{2}$
}

\begin{abstract}
Necker Island, a remote island located in the Northwestern Hawaiian Islands, provides a unique opportunity to investigate species-level algal and benthic invertebrate assemblages and assess temporal variation of coral reef ecosystems exposed to minimal anthropogenic impacts. This study provides a robust baseline of common benthic species at Necker Island and their relative abundances before any known ecological response to changing oceanographic conditions. Rapid ecological assessment (REA) methods using photoquadrat imagery from long-term monitoring sites coupled with towed-diver surveys conducted between 2002 and 2006 were analyzed to determine percentage cover of benthic organisms around the island, and macroalgal species lists were compiled from voucher specimens. Benthic substrates were typically dominated by turf algae at all sites for all years, and macroalgal and coral covers were found to be low. A total of 25 macroalgal and 11 anthozoan species was identified. Of these, 13 macroalgal species and one coral species represent new records for Necker Island. Analyses of community similarity found spatial differences among sites in 2006, as well as temporal differences between 2005 and 2006, an outcome primarily driven by significant increases in percentage cover of macroalgae and coral at one site. However, benthic communities observed during extensive towed-diver surveys around Necker Island did not identify significant differences among geographical sectors or years, suggesting that benthic communities are relatively homogeneous. Necker Island contains macroalgal and coral populations similar to those of neighboring reef systems within the Northwestern Hawaiian Islands, and this study provides a baseline of benthic assemblages for ongoing temporal monitoring.
\end{abstract}

\begin{abstract}
${ }^{1}$ Manuscript accepted 17 January 2011. Funding from the Office of Habitat Conservation at NOAA Fisheries as part of NOAA's Coral Reef Conservation Program supported this work. Funding to CRED for scientific expeditions to the Northwestern Hawaiian Islands was provided by the NOAA Coral Reef Conservation Program.

${ }^{2}$ Joint Institute for Marine and Atmospheric Research and NOAA Fisheries, Pacific Islands Fisheries Science Center, Coral Reef Ecosystem Division, 1125b Ala Moana Boulevard, Honolulu, Hawai'i 96814.

${ }^{3}$ Corresponding author. Current address: Rosenstiel School of Marine and Atmospheric Science, University of Miami, 4600 Rickenbacker Causeway, Miami, Florida 33149 (e-mail: sschopmeyer@rsmas.miami.edu).
\end{abstract}

Pacific Science (2011), vol. 65, no. 4:405-417

doi: $10.2984 / 65.4 .405$

(C) 2011 by University of Hawai'i Press

All rights reserved
Papahānaumokuākea Marine National Monument (PMNM) in the Northwestern Hawaiian Islands (NWHI) is among the largest marine protected areas in the world and is considered to contain one of the most pristine coral reef ecosystems in existence (Friedlander et al. 2009). The 10 islands in PMNM provide unprecedented opportunities for scientists and managers to study relatively intact subtropical coral reefs and evaluate natural marine ecosystem processes. Prior research in this area has documented thriving, top predator-dominated fish communities (Friedlander and DeMartini 2002, Holzwarth et al. 2006a,b) and healthy benthic communities containing extensive hard-bottomed, algal-dominated assemblages interspersed with patches of dense coral cover (Maragos and Gulko 2002, Friedlander et al. 2005, Vroom et al. 2005, 2006, Vroom and Braun 
2010). However, few studies have quantitatively documented species-level, spatial benthic community structure or temporal variation (Maragos and Gulko 2002, Friedlander et al. 2004, Vroom et al. 2005, Vroom and Timmers 2009, Vroom and Braun 2010) for islands within PMNM. To protect and conserve these valuable ecosystems, it is imperative to understand the spatial and temporal variation of benthic reef communities and establish baseline values of coral and algal abundance, distribution, and diversity before large-scale environmental changes.

Necker Island (Mokumanamana) is a 0.2 $\mathrm{km}^{2}$ hook-shaped basalt island located within PMNM (23 $\left.28^{\prime} \mathrm{N}, 164^{\circ} 33^{\prime} \mathrm{W}\right), 249 \mathrm{~km}$ northwest of Nìhoa Island (Figure 1). Al- though one of the smallest islands in the NWHI, the submerged bank surrounding Necker Island has almost $1,600 \mathrm{~km}^{2}$ of potential hard-bottomed reef habitat (Rohmann et al. 2005). Immediately adjacent to shore, the island is surrounded by a shallow $(<50 \mathrm{~m})$ shelf that is subjected to moderate to severe wave action throughout much of the year. This inhibits extensive shallow-water coral reef development and has subsequently resulted in low coral cover within nearshore habitats (Maragos et al. 2004, Parrish and Boland 2004, Grigg et al. 2008). Although the coastal waters surrounding the island have historically been used for commercial fishing, in particular bottomfisheries for snapper, grouper, and jacks (Hau 1984) and lobster

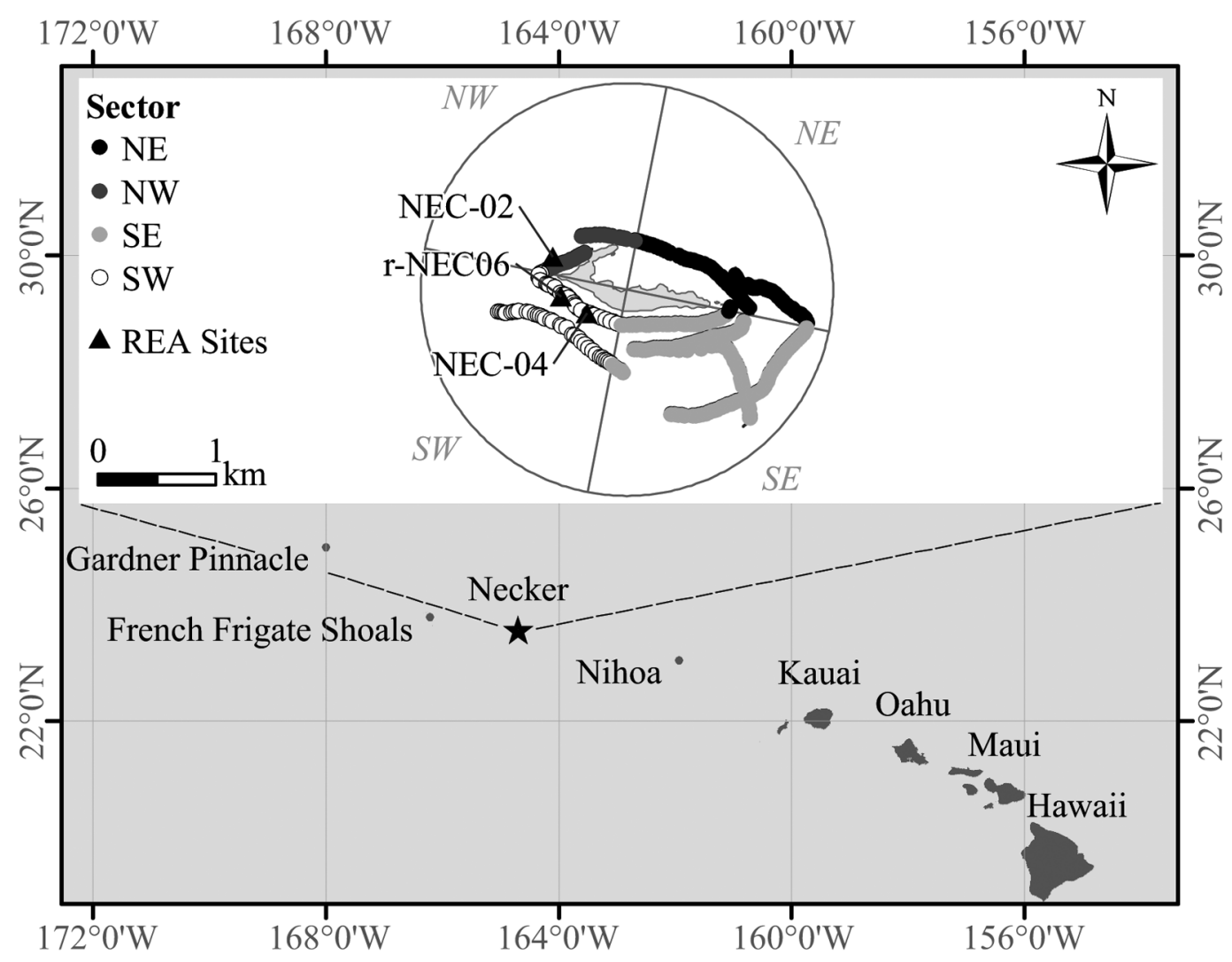

FIGURE 1. Map of Hawaiian archipelago showing location of Necker Island. Black triangles represent rapid ecological assessment (REA) monitoring sites, and gray scale dots represent towed-diver survey tracks within four geographical sectors (NW, NE, SE, and SW). 
trapping (Pooley and Kawamoto 1998, DeMartini et al. 2003), Necker Island has remained virtually uninhabited except for use by the ancient Hawaiians as a site for religious ceremonies (Emory 1928, Cleghorn 1988). Thus, Necker Island is one of the least anthropogenically impacted islands in recent history in the Hawaiian archipelago. Previous studies provide only a cursory glimpse of coral community composition and diversity for Necker Island (Grigg 1983), and, currently, only rudimentary lists of algal species exist (Abbott 1989, 1999, Abbott and Huisman 2004).

Joint research expeditions to Necker Island since 2000, led by the National Oceanic and Atmospheric Administration's (NOAA) $\mathrm{Pa}-$ cific Islands Fisheries Science Center (PIFSC) Coral Reef Ecosystem Division (CRED) and PMNM, provide unprecedented, ecosystembased surveys that allow researchers to examine species and functional group diversity to measure healthy ecosystem fluctuations and study ecological responses to oceanographic conditions. This study presents the first comprehensive percentage cover analysis of coral and macroalgae at the species level and investigates spatial and temporal benthic diversity patterns at Necker Island before evidence of major anthropogenic or environmental changes. The goals of this study were to (1) determine dominant invertebrate (coral) and macroalgal species that occur in benthic communities at established monitoring sites, (2) establish spatial relationships of benthic communities at sites surveyed, and (3) examine natural temporal fluctuations in benthic community composition at Necker Island from 2002 to 2006.

\section{MATERIALS AND METHODS}

\section{Field Sampling}

Quantitative rapid ecological assessments (REA) of benthic composition were conducted at three established, long-term monitoring sites on the west side of Necker Island in 2002, 2003, 2005, and 2006 (NEC-02, NEC04, and rNEC-06 (Table 1, Figure 1). Criteria for selection of long-term monitoring sites included representation of typical biological habitats and communities and a high probability of annual accessibility to divers under prevalent sea conditions. A Global Positioning System (GPS) position and compass heading of transects at each site were recorded to ensure that similar habitats were sampled during each survey year. REA surveys of benthic communities were conducted along two nonpermanent $25 \mathrm{~m}$ transect lines at $\sim 14 \mathrm{~m}$ depth at each site (Figure 1, Table 1). Scuba divers photographically recorded benthic substrate cover in 12 quadrats $(35 \times 50 \mathrm{~cm})$ at each site with a 4.0 megapixel digital still camera (Sony DSC P-9): six quadrats at randomly selected points along the transect lines (three per transect) and six quadrats at points $3 \mathrm{~m}$

TABLE 1

Established NOAA Rapid Ecological Assessment Survey Sites at Necker Island

\begin{tabular}{|c|c|c|c|c|}
\hline Site No. & Date & Latitude & Longitude & Transect Depth (m) \\
\hline NEC-02 & $\begin{array}{l}\text { *14 July } 2003 \\
\text { 4 October } 2005 \\
3 \text { September } 2006\end{array}$ & $23^{\circ} 34.693^{\prime} \mathrm{N}$ & $164^{\circ} 42.384^{\prime} W$ & $13.3-18.0$ \\
\hline NEC-04 & $\begin{array}{l}\text { 10 September } 2002 \\
14 \text { July } 2003 \\
\text { *4 October } 2005 \\
3 \text { September } 2006\end{array}$ & $23^{\circ} 34.437^{\prime} \mathrm{N}$ & $164^{\circ} 42.228^{\prime} \mathrm{W}$ & $11.9-13.1$ \\
\hline rNEC-06 & $\begin{array}{l}\text { *14 July } 2003 \\
4 \text { October } 2005\end{array}$ & $23^{\circ} 34.511^{\prime} \mathrm{N}$ & $164^{\circ} 42.348^{\prime} \mathrm{W}$ & $9.1-12.2$ \\
\hline
\end{tabular}

Note: Dates marked with an asterisk $\left(^{*}\right)$ indicate when only algal samples were collected but no quantitative data were collected. 
perpendicular from each random point in the direction of shallower water (Preskitt et al. 2004, Vroom et al. 2005).

Towed-diver surveys conducted around Necker Island in 2003 (southern coast of island only) and 2006 according to methodologies described by Kenyon et al. (2006a) were used to photographically record benthic habitat from which computerized images were analyzed to determine percentage cover of benthic organisms at the functional group level (Figure 1). The only modification to the method of Kenyon et al. (2006a) involved the use of a 6.3 megapixel digital still camera (Canon EOS-10D) with an EF $20 \mathrm{~mm}$ lens instead of a video camera. The camera was fitted into a customized housing with strobes mounted on towed-diver survey boards to photograph the benthos automatically at 15 -sec intervals during a 50-min tow survey. Survey tracks were mapped using a GPS and ArcGIS software (Figure 1). For the analyses presented here, every other image was analyzed to determine benthic functional group composition, resulting in 30-sec intervals between analyzed images.

\section{Taxonomic Identification of Algae}

Macroalgae were hand collected by scuba divers at long-term REA monitoring sites around Necker Island in 2002, 2003, 2005, and 2006 from within photoquadrats, as well as during qualitative surveys, along each transect line. Algal voucher specimens were immediately frozen after collection. After the completion of each expedition, macroalgal herbarium pressings were made, and voucher specimens were taxonomically identified to the species level. Specimens were then deposited at the Herbarium Pacificum at the Bishop Museum in Honolulu, Hawai'i (PSV20690 to PSV20803). Approximately 680 slides of numerous epiphyte and turf algal species collected during surveys were made but remain to be taxonomically identified.

\section{Analyses of Benthic Composition}

All REA photoquadrats and towed-diver images were analyzed by the same individual (S.
Schopmeyer and C. Wilkinson, respectively) using Coral Point Count with Microsoft Excel extensions software (CPCe version 3.5, Dania Beach, Florida [Kohler and Gill 2006]). Each analyst has extensive experience identifying benthic organisms in the NWHI, providing assurance of proper classification within benthic imagery. For analysis of REA photoquadrats, 100 stratified random points (one random point placed in each box of a $10 \times 10$ grid within $\mathrm{CPCe}$ ) were placed on each REA digital image (300 dpi). Macroalgae and corals were identified to the species level when possible, and turf algae, crustose coralline red algae (CCA), cyanobacteria, and other benthic macroinvertebrates, such as urchins and sponges, were classified into functional groups. Stratified random points were used rather than random points to ensure even coverage of photoquadrats by preventing points from clumping in select areas. Percentage cover was subsequently estimated by identifying benthic organisms or substrate type under each point. For towed-diver images, 50 stratified random points were placed on each image, and benthic cover was categorized into the following functional groups: coral, macroinvertebrates, macroalgae, CCA, or turf algae. Substrate types (e.g., pavement, rock, or rubble) were categorized by the type of living organism covering them (typically turf algae). Sand was kept as its own independent category. Species identification and relative percentage cover determined from image analyses were compared to in situ diver observations collected during REA belt transects and towed-diver surveys for quality assurance. For REA photoquadrats, percentage cover data from each quadrat were treated as individual replicates within a site, and a BrayCurtis similarity matrix of quadrats was created using PRIMER-E, version 6 (Clarke and Warwick 2001, Clarke and Gorley 2006). Before analysis, a fourth-root transformation was performed on quantitative data to reduce the influence of prevalent species and increase the weight of rare species. Year and site were provided as factors. For towed-diver images, percentage cover data from each photograph were treated as individual replicates within a geographical sector, and a Bray-Curtis simi- 
larity matrix of quadrats was created using untransformed data with year and sector provided as factors.

\section{Statistical Analyses}

To explore spatial and temporal distributional patterns between sites, REA photoquadrat data and towed-diver image data were separated by year before analyses. In addition, towed-diver survey images were grouped into geographical island sectors (NW, NE, SE, and $\mathrm{SW}$ ) to determine if tow images from within each sector were spatially or temporally similar. One-way analyses of similarity (ANOSIM; maximum permutations $=5,000$ ) were conducted to determine if spatial differences existed among sites or sectors within a single sampling year. Next, a one-way ANOSIM was performed on the complete
REA and towed-diver data set by year to determine if temporal differences occurred (all sites or sectors together within a single year). A two-way crossed ANOSIM was conducted to investigate whether individual sites or sectors exhibited temporal changes in benthic community composition. Finally, SIMPER (similarity percentages routine) analyses using nontransformed data explored the contribution of individual species or functional groups when ANOSIM analyses detected differences.

\section{RESULTS}

\section{Algal Cover}

A total of seven macroalgal species was identified within REA photoquadrats from all sampling years, with an additional 18 macroalgal species being found during qualitative surveys at long-term monitoring sites (Table 2). Of

\section{TABLE 2}

Macroalgal Species Identified from REA Surveys

\begin{tabular}{|c|c|c|c|}
\hline Division & Order & Family & Species \\
\hline \multirow[t]{14}{*}{ Rhodophyta } & Bonnemaisoniales & Bonnemaisoniaceae & $\begin{array}{l}\text { Asparagopsis taxiformis* (Delile) Trevisan de } \\
\text { Saint-Léon }\end{array}$ \\
\hline & \multirow[t]{6}{*}{ Ceramiales } & Dasyaceae & Dasya iridescens* (Schlech) Millar \& Abbott \\
\hline & & Delesseriaceae & Martensia fragilis* Harvey \\
\hline & & Rhodomelaceae & Laurencia galtsoffii Howe \\
\hline & & & Laurencia majuscula (Harvey) Lucas \\
\hline & & & Amansia glomerata C. Agardh \\
\hline & & & Tolypiocladia glomerulata* (C. Agardh) Schmitz \\
\hline & \multirow{2}{*}{ Gigartinales } & Dumontiaceae & Gibsmithia hawaiiensis* Doty \\
\hline & & Rhizophyllidaceae & Portieria bornemannii* (Lyngbye) Silva \\
\hline & Nemaliales & Galaxauraceae & Galaxaura rugosa* (Ellis \& Solander) Lamouroux \\
\hline & Plocamiales & Plocamiaceae & Plocamium sandvichense J. Agardh \\
\hline & \multirow{3}{*}{ Rhodymeniales } & Champiaceae & Champia parvula* (C. Agardh) Harvey \\
\hline & & Lomentariaceae & Gelidiopsis intricata* (C. Agardh) Vickers $^{*}$ \\
\hline & & Rhodymeniaceae & Halichrysis irregularis* (Kützing) Millar \\
\hline \multirow[t]{7}{*}{ Chlorophyta } & Cladophorales & Anadyomenaceae & Microdictyon setchellianum Howe \\
\hline & Siphoncladales & Valoniaceae & Valonia ventricosa ${ }^{*} \mathrm{~J}$. Agardh \\
\hline & \multirow[t]{5}{*}{ Bryopsidales } & Caulerpaceae & Caulerpa antoensis Yamada \\
\hline & & & Caulerpa racemosa (Forsskål) J. Agardh \\
\hline & & & Caulerpa taxifolia (Vahl) C. Agardh \\
\hline & & & Caulerpa webbiana Montagne \\
\hline & & Halimedaceae & $\begin{array}{l}\text { Halimeda opuntia* (Linnaeus) Lamouroux } \\
\text { Halimeda velasquezii Tavlor }\end{array}$ \\
\hline \multirow[t]{3}{*}{ Heterokontophyta } & \multirow[t]{2}{*}{ Dictyotales } & \multirow[t]{2}{*}{ Dictyotaceae } & Dictyota ceylanica Kützing \\
\hline & & & $\begin{array}{l}\text { Lobophora variegata (Lamouroux) Womersley ex } \\
\text { Oliveira }\end{array}$ \\
\hline & Fucales & Sargassaceae & Turbinaria ornata* (Turner) J. Agardh \\
\hline
\end{tabular}

Note: New records for Necker Island are indicated by an asterisk $\left(^{*}\right)$. 
TABLE 3

Mean Percentage Cover (SE) of Benthic Organisms at REA Monitoring Sites at Necker Island, NWHI, Segregated by Year

\begin{tabular}{|c|c|c|c|c|c|c|}
\hline \multirow{2}{*}{$\begin{array}{l}\text { Year } \\
\text { Site }\end{array}$} & \multirow{2}{*}{$\frac{2002}{\text { NEC-04 }}$} & \multirow{2}{*}{$\frac{2003}{\text { NEC-04 }}$} & \multicolumn{2}{|c|}{2005} & \multicolumn{2}{|c|}{2006} \\
\hline & & & NEC-02 & rNEC-06 & NEC-02 & NEC-04 \\
\hline \multicolumn{7}{|l|}{ Coral species } \\
\hline Acropora valida* & $0.3(0.3)$ & & & & & \\
\hline Leptastrea purpurea & & & $0.1(0.1)$ & $0.1(0.1)$ & & \\
\hline Montipora capitata & & & $0.1(0.1)$ & & $0.7(0.4)$ & $0.1(0.1)$ \\
\hline Pocillopora eydouxi & $0.1(0.1)$ & $0.2(0.2)$ & & & & \\
\hline Pocillopora ligulata & & & & & $0.1(0.1)$ & \\
\hline Pocillopora meandrina & $0.5(0.3)$ & $2.7(1.7)$ & $2.2(0.9)$ & $0.7(0.5)$ & $1.8(1.6)$ & $4.2(2.0)$ \\
\hline Porites brighami & & $0.2(0.1)$ & $0.2(0.2)$ & & & \\
\hline Porites compressa & & & & & $1.1(0.8)$ & $0.1(0.1)$ \\
\hline Porites evermanni & & & $0.3(0.3)$ & & $0.8(0.4)$ & $1.2(0.7)$ \\
\hline Porites lobata & $5.0(1.5)$ & $4.1(1.1)$ & $7.1(2.4)$ & $5.0(1.3)$ & $20.7(4.6)$ & $2.5(0.8)$ \\
\hline Coral total & $5.9(1.6)$ & $7.2(1.8)$ & $10.0(2.3)$ & $5.8(1.3)$ & $25.2(4.8)$ & $8.1(2.3)$ \\
\hline Other anthozoans & & & $1.3(0.9)$ & & & \\
\hline \multicolumn{7}{|l|}{ Macroalgal species } \\
\hline Dasya iridescens* & $0.1(0.1)$ & & & & & \\
\hline Dictyota ceylanica & & & & & $1.0(0.7)$ & \\
\hline Gibsmithia bawaiiensis* & $0.1(0.1)$ & & & & & $0.1(0.1)$ \\
\hline Halimeda opuntia* & $0.8(0.8)$ & & & & & \\
\hline Halimeda velasquezii & $7.4(2.6)$ & $5.9(1.6)$ & $5.5(1.5)$ & $6.2(0.8)$ & $15.9(2.0)$ & $6.6(1.2)$ \\
\hline Laurencia galtsoffii & $0.2(0.1)$ & $0.1(0.1)$ & & $1.1(0.5)$ & & $0.2(0.1)$ \\
\hline Microdictyon setchellianum & & & & & & $0.3(0.3)$ \\
\hline Macroalgal total & $8.6(2.6)$ & $6.0(1.7)$ & $5.5(1.5)$ & $7.3(1.3)$ & $16.9(2.7)$ & $7.1(1.7)$ \\
\hline Turf algae & $82.1(4.1)$ & $85.6(3.4)$ & $81.4(3.3)$ & $86.0(1.2)$ & $56.0(4.9)$ & $83.6(3.4)$ \\
\hline Crustose coralline red algae & $0.6(0.3)$ & $0.2(0.2)$ & $1.3(0.3)$ & $0.5(0.4)$ & $0.9(0.3)$ & $0.3(0.2)$ \\
\hline Cyanobacteria & $1.0(1.0)$ & $0.6(0.4)$ & $0.1(0.1)$ & $0.1(0.1)$ & & $0.4(0.2)$ \\
\hline
\end{tabular}

Note: Species marked with an asterisk $\left(^{*}\right)$ indicate a new species record.

these, 13 are new records for Necker Island (Table 2). Benthic substrates were dominated by turf algae (range $=56.0 \%$ to $86.0 \%$ ) at all sites for all years (Table 3, Figure 2). Macroalgal cover varied slightly between years, with lowest cover occurring in $2003(6.0 \%)$ and highest cover occurring in 2006 (12.0\%). The calcified green alga Halimeda velasquezii exhibited the highest percentage cover at all sites in all years (range $=5.5 \%$ to $15.9 \%$ ). The second most commonly observed macroalgal species, although with low cover, was the red alga Laurencia galtsoffii (range $=0.2 \%$ to $1.1 \%$ ) at sites NEC-04 and rNEC-06 during all years surveyed (Table 3). Percentage cover of CCA (range $=0.2 \%$ to $1.3 \%$ ) was low at all sites in all years (Table 3 ). Similarly, cyano- bacteria were observed at all sites except NEC-02 in 2006 with a low percentage cover (range $=0.1 \%$ to $1.0 \%$ [Table 2]).

Towed-diver image analysis revealed findings similar to REA photoquadrats with benthic cover around Necker Island dominated by turf algal assemblages (range $=45.1 \%$ to $78.7 \%$ [Table 4]) in 2003 and 2006. Average island-wide macroalgal cover increased slightly between years from $4.0 \%$ in 2003 to $11.4 \%$ in 2006 as a result of high macroalgal cover $(27.9 \%)$ observed in the NW sector in 2006. This sector was not surveyed using towed-diver methodologies in 2003. Average island-wide crustose coralline red algal cover was observed to range between $0.2 \%$ in 2003 to $3.1 \%$ in 2006 . 


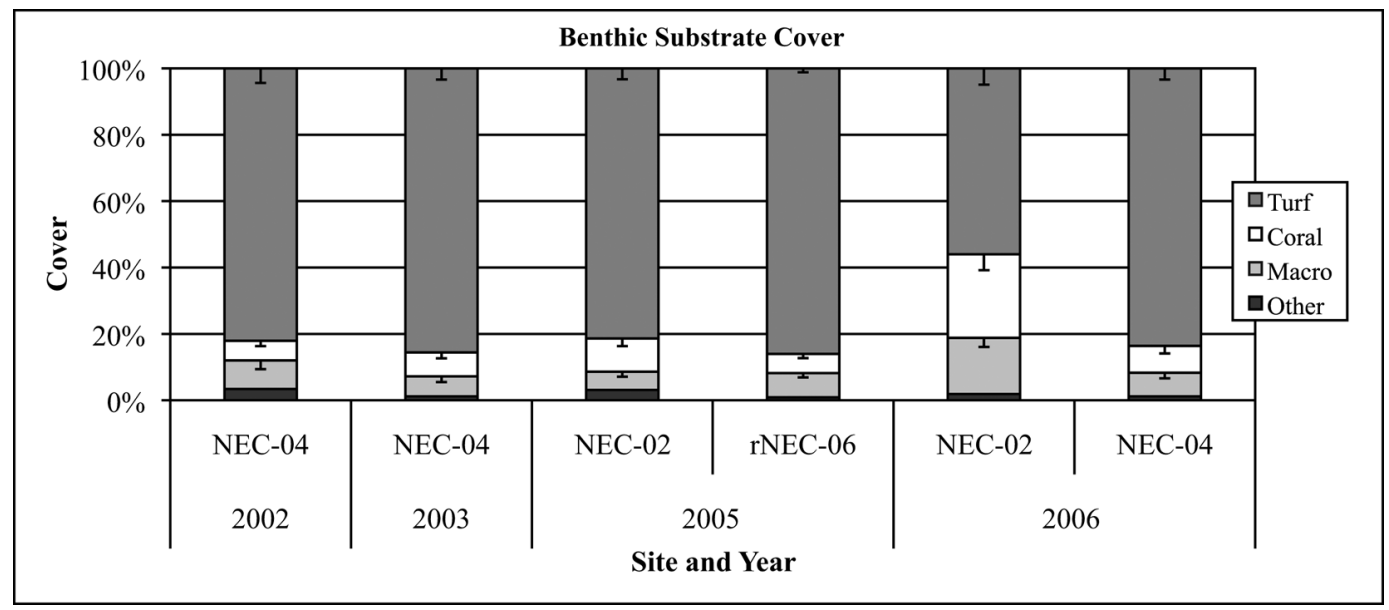

Figure 2. Percentage cover of benthic functional groups at Necker Island as determined through REA surveys. Macro = macroalgae; Other $=$ crustose coralline red algae, cyanobacteria, and sessile noncoral macroinvertebrates.

TABLE 4

Mean Percentage Cover (SE) of Benthic Organisms by Sector as Recorded from Towed-Diver Surveys around Necker Island, NWHI, Segregated by Year

\begin{tabular}{|c|c|c|c|c|c|c|}
\hline \multirow{2}{*}{$\begin{array}{l}\text { Year } \\
\text { Sector }\end{array}$} & \multicolumn{2}{|c|}{2003} & \multicolumn{4}{|c|}{2006} \\
\hline & SW & SE & $\mathrm{NW}$ & $\mathrm{NE}$ & SW & SE \\
\hline \multicolumn{7}{|c|}{ Species/Functional Group } \\
\hline Acropora sp. & 0.0 & 0.0 & 0.0 & 0.0 & 0.0 & 0.0 \\
\hline Montipora sp. & 0.0 & 0.0 & 0.0 & 0.0 & $0.1(0.1)$ & 0.0 \\
\hline Pocillopora sp. & 0.0 & 0.0 & $0.3(0.2)$ & 0.0 & 0.0 & 0.0 \\
\hline Porites sp. & $0.4(0.1)$ & $0.8(0.4)$ & $3.6(0.8)$ & $9.4(1.0)$ & $3.7(1.0)$ & $3.2(0.5)$ \\
\hline Porites compressa & $6.7(1.7)$ & $1.2(0.4)$ & $16.8(2.6)$ & $9.5(1.2)$ & $8.2(2.3)$ & $1.9(0.3)$ \\
\hline Other live coral & $0.1(0.1)$ & 0.0 & $0.9(0.6)$ & $0.2(0.1)$ & 0.0 & 0.0 \\
\hline Coralline algae & $0.4(0.2)$ & $0.1(0.0)$ & $4.0(1.0)$ & $5.0(0.8)$ & $2.5(1.1)$ & $0.7(0.2)$ \\
\hline Macroalgae & $5.3(1.2)$ & $2.7(0.7)$ & $27.9(3.9)$ & $8.8(1.6)$ & $4.3(1.4)$ & $4.6(0.9)$ \\
\hline Turf algae & $70.8(3.7)$ & $68.3(4.8)$ & $45.1(5.2)$ & $65.9(2.8)$ & $78.7(3.7)$ & $73.6(2.4)$ \\
\hline Sand & $16.2(3.7)$ & $26.9(5.1)$ & $1.3(0.5)$ & $1.1(0.3)$ & $2.6(0.9)$ & $15.9(2.3)$ \\
\hline
\end{tabular}

\section{Macroinvertebrate Cover}

A total of 10 scleractinian corals and one zoanthid species was identified within REA photoquadrats from all survey years (Table 3). Of these, one coral species, Acropora valida, is a new record for Necker Island (Table 3). Mean percentage cover of live coral was similar between $2002(5.9 \%), 2003(7.2 \%)$, and 2005 (7.9\%); however, in 2006, mean percentage coral cover increased to $16.6 \%$ because of a threefold increase in the occurrence of Porites lobata at NEC-02 (Table 3, Figure 2). Coral cover at all sites in all years was dominated by mounding and encrusting colonies of Porites lobata (range $=2.5 \%$ to $20.7 \%$ ) and branching colonies of Pocillopora meandrina (range $=0.5 \%$ to $4.2 \%$ [Table 3]). Members of the genus Porites, including P. evermanni (1.2\%) and $P$. compressa $(1.1 \%)$, were the only other coral species to exhibit percentage cover greater than $1 \%$ at surveyed sites (Table 3 ). Colonies 
of Zoanthus pacifica, the only zoanthid observed in photoquadrats at Necker Island, contributed to $1.3 \%$ of benthic cover at NEC02 in 2005 (Table 3). The occurrence of macroinvertebrates within REA photoquadrats was low in all years and represented only 0.08\% (2002), 0.00\% (2003), 0.30\% (2005), and $0.06 \%$ (2006) of total benthic cover.

Average islandwide percentage cover of coral species recorded during towed-diver surveys ranged between $4.6 \%$ in 2003 and $14.5 \%$ in 2006. Similar to findings at REA sites, coral cover recorded by conducting towed-diver surveys during both years was dominated by colonies of the genus Porites and Pocillopora during both survey years $(5.9 \%$ and $3.8 \%$ cover, respectively). A low occurrence of noncoral macroinvertebrates was found during towed-diver surveys $(0.04 \%$ [2003] and $0.03 \%$ [2006] of total benthic cover).

\section{Spatial Analyses}

In 2002 and 2003, only one site (NEC-04) was surveyed using REA methodologies, thus limiting statistical spatial analyses to 2005 and 2006 (Table 1). In 2005, no difference in benthic community composition was detected between sites NEC-02 and rNEC-06 (ANOSIM Global-R $=0.096, P=.064$ [Table 3]). However, a significant difference between benthic communities was observed between NEC-02 and NEC-04 in 2006 (ANOSIM Global$\mathrm{R}=0.349, P<.0002)$. Significant differences between these sites were driven primarily by three species/functional groups: turf algae, Porites lobata, and Halimeda velasquezii (Table $3)$. In 2006, the dominant organisms at both NEC-02 and NEC-04 were turf algae, although NEC-04 exhibited a cover of $83.5 \%$, but NEC-02 exhibited a cover of only $56.0 \%$. Conversely, mean cover of Porites lobata and Halimeda velasquezii was found to be higher at NEC-02 (20.7\% and 15.9\%, respectively) than at NEC-04 $(2.5 \%$ and $6.6 \%$, respectively). When results of statistical analyses using towed-diver data were examined, no significant differences between benthic community composition among geographical sectors were observed (ANOSIM Global-
$\mathrm{R}=0.111, \quad P=.0001)$. All sectors within towed-diver images were dominated by turf and macroalgal assemblages in both years.

\section{Temporal Analysis}

Global ANOSIM testing for differences between years using data from REA sites found no temporal differences in benthic community structure at Necker Island (ANOSIM Global-R $=0.119, \quad P=.0002$ ) from 2002 through 2006. However, although individual pairwise comparisons detected no significant differences in benthic communities between 2002 and 2003 (ANOSIM Global-R $=0.067$, $P=.069$ ), 2002 and 2006 (ANOSIM Global$\mathrm{R}=0.075, \quad P=.07), \quad$ or 2003 and 2006 (ANOSIM Global-R $=0.011, P=.316$ ), a slight difference between benthic communities was noted from 2005 to 2006 (ANOSIM Global-R $=0.265, P=.0002$ ) as a result of changes in percentage cover of turf algae, Porites lobata, and Halimeda velasquezii at NEC-02 (Table 3). At that site, percentage cover of turf algae decreased from $81.4 \%$ (2005) to $56.0 \%$ (2006), and percentage cover of both Porites lobata (7.1\% in 2005 to $20.7 \%$ in 2006) and Halimeda velasquezii (5.5\% in 2005 to $15.9 \%$ in 2006) increased (Table 3). This temporal difference at NEC-02 was not statistically strong enough to make islandwide temporal comparisons between all sites significant in the global test (Table 3). In addition, no significant temporal differences in benthic assemblages were detected between towed-diver surveys conducted in 2003 or 2006 (ANOSIM Global-R $=0.059, P=.011$ ).

\section{DISCUSSION}

This study provides the first multidisciplinary spatial and temporal comparisons of benthic communities from Necker Island, Northwestern Hawaiian Islands, and forms a critical baseline for future monitoring efforts. Observations presented here increase the number of documented algal species at Necker Island from 44 (Abbott 1989) to 57 and found algae to play a dominant role in reef communities.

Turf algal communities dominated substrata $(79.1 \%$ cover $)$ surveyed at REA sites for 
all years combined, a finding similar to reports from other reefs in the NWHI, such as French Frigate Shoals (78.1\%) in 2002 (Vroom et al. 2005) and Gardner Pinnacles $(74.6 \%)$ in 2004 (Vroom and Timmers 2009), both of which relied on the same photoquadrat survey techniques used in this study. In addition, percentage cover of turf algal communities as determined from both REA and towed-diver surveys during this study are comparable (79.1\% and $67.7 \%$, respectively).

Percentage cover of macroalgae as determined through REA surveys was 8.6\% (sites and years combined), which is lower than observed macroalgal cover at French Frigate Shoals $(15.9 \%$ [Vroom et al. 2005]) and Gardner Pinnacles (18.0\% [Vroom and Timmers 2009]). Slight variations in mean annual macroalgal cover were detected when comparing REA photoquadrats and towed-diver surveys (4.0\% in 2003 and $11.4 \%$ in 2006), but these differences were not significant and may reflect natural temporal variability of this functional group rather than differences in sampling protocols. Although prior research found the green alga Microdictyon setchellianum to be abundant at French Frigate Shoals (Vroom et al. 2005) and Gardner Pinnacles (Vroom and Timmers 2009), a low percentage cover of this species was seen at only one site at Necker Island in 2006. No effect of the deepwater bloom of the nonnative, invasive red alga Hypnea musciformis documented around Necker Island in 2005 (Friedlander et al. 2005) was evident in the nearshore environments surveyed during the sampling efforts reported here.

Cyanobacterial and crustose coralline red algal functional groups each only covered $0.6 \%$ of substrata, indicating that populations of these functional groups were lower at Necker Island than at Gardner Pinnacles, where they covered $4.6 \%$ and $6.1 \%$ of the substrate, respectively (Vroom and Timmers 2009), and at French Frigate Shoals, where CCA covered $15.5 \%$ of the substrate and cyanobacterial populations were negligible (Vroom et al. 2005). The low presence of CCA on benthic substrates at Necker Island may be of particular interest because of its ability to chemically induce the settlement of several species of coral larvae and, therefore, low CCA cover may result in relatively low coral recruitment at Necker Island compared with other islands in PMNM (Morse et al. 1988, Morse et al. 1996, Heyward and Negri 1999).

The number of coral species recorded during REA surveys was relatively low when compared with past studies from Necker Island (Grigg 1983) and with the NWHI as a whole (Friedlander et al. 2008). Fifty-seven species of coral are known to occur in the NWHI (Maragos et al. 2004), with up to 21 species of coral documented at Necker Island (Grigg 1983, Maragos et al. 2009). However, one species, Acropora valida, reported during our surveys was a new species record for Necker Island (Table 3). Not all species observed in previous studies were documented in photoquadrat analysis during this study, and it is likely that the small physical size of sampled quadrats may not have adequately captured diversity of less-common species previously documented at Necker Island.

Mean percentage coral cover was relatively low for all survey years, although the occurrence of coral cover at one REA survey site did increase from $7.1 \%$ in 2002 to $20.7 \%$ in 2006, a trend similar to that observed by Friedlander et al. (2008) using in situ diver observations at Necker Island between 2002 and 2006. However, although this phenomenon has been recorded in two different studies, the drastic rise in coral cover over such a short time scale in our analysis may also be attributable to the use of nonpermanent random transect placement between years and may not correspond to actual increases in coral cover. Regardless, this finding emphasizes the importance of robust baseline data and the need for continual monitoring of benthic assemblages to discern between small-scale normal fluctuations in benthic cover and large-scale emergent patterns of permanent change and potential phase shifts of coral reefs from coral to macroalgal dominated or vice versa (Done 1992, Hughes 1994, McManus and Polsenberg 2004).

Islandwide values of percentage coral cover determined from imagery recorded during towed-diver surveys in 2003 (4.6\%) and 2006 
(11.8\%) were similar to mean percentage coral cover data derived from REA photoquadrat analysis presented here $(10.3 \%)$, indicating that the methodologies used during this study were adequate for estimating overall percentage coral cover for Necker Island. Coral percentage cover ranges at Necker Island were slightly higher than those observed on forereefs at French Frigate Shoals, the closest neighboring reef system to Necker Island $(6.5 \%-8.8 \%$ [Vroom et al. 2005, Kenyon et al. 2006b]), and at Gardner Pinnacles (5.0\% [Vroom and Timmers 2009]).

Benthic assemblages at Necker Island were found to be similar to those of other basaltic islands in the southern end of PMNM, such as Nihoa (Maragos et al. 2009) and Gardner Pinnacles (Vroom and Timmers 2009). Like Necker Island, these small islands are exposed to high wave energy and are documented to have low species richness and coral cover (Friedlander et al. 2008, Maragos et al. 2009) and are dominated by robust coral species, such as Porites lobata and Pocillopora meandrina, which are more tolerant of high wave action. It is surprising that percentage cover of coral and algae at Necker Island was also found to be similar to benthic cover at French Frigate Shoals (Kenyon et al. 2006b, Vroom et al. 2006), a large limestone atoll, although Necker Island contained only about one-third of the coral species richness observed at French Frigate Shoals (Maragos et al. 2009). The large atolls located toward the middle of PMNM, such as French Frigate Shoals and Maro Reef, are characterized by some of the highest coral and algal species richness in the NWHI, reflecting heterogeneity of both habitats and environmental reef conditions (Maragos et al. 2009) in larger reef systems.

Although islandwide towed-diver surveys did not reveal any significant spatial patterns between benthic communities at Necker Island, slight spatial differences were observed between NEC-02 and NEC-04 in 2006 REA photoquadrats primarily because of differences in abundance of Porites lobata and Halimeda velasquezii turf algal populations. Although benthic communities at each of those survey sites were found to be similar during other survey years, it is possible that spatial differences in percentage cover between those two sites in 2006 represent typical benthic heterogeneity in reef ecosystems. However, no spatial differences were observed in towed-diver surveys between geographical sectors. Species-level shifts in benthic composition may vary spatially (as shown by REA analyses), but there is little spatial variation across the island at the coarser functional-group level (as shown by toweddiver surveys). This suggests a strong need for continuous, comprehensive ecosystem-based monitoring at the species level to adequately detect spatial variation in benthic communities.

Temporal comparisons revealed no significant differences in benthic community composition between most years for REA surveys, although individual pairwise comparisons testing specific years found differences to occur between 2005 and 2006 at one site. Since benthic communities were shown to differ between NEC-02 and NEC-04, data indicated that the absence of surveys at NEC04 or the presence of surveys at rNEC-06 in 2005 may have masked a significant change in overall temporal comparisons. Analysis shows that there was a slight temporal change in benthic communities at NEC-02 between 2005 and 2006, but those changes were not extensive enough to affect global temporal comparisons. Oceanographic conditions, including sea-surface temperatures (SST) and local wave energy (significant wave height $=$ $\left.H_{S}\right)$, recorded by NOAA's National Data Buoy Center Station 51001, around Necker Island were temporally stable between 2005 (mean $\mathrm{SST}=25.1^{\circ} \mathrm{C}[\mathrm{SD} 1.7]$, $\min \mathrm{SST}=$ $20.9^{\circ} \mathrm{C}$, max SST $=30.4^{\circ} \mathrm{C}$; mean $H_{S}=2.4 \mathrm{~m}$ [SD 0.9], $\min H_{S}=0.9 \mathrm{~m}, \max H_{S}=8.0 \mathrm{~m}$ ) and 2006 (mean SST $=25.4^{\circ} \mathrm{C}$ [SE 1.4], $\mathrm{min}$ $\mathrm{SST}=23.1^{\circ} \mathrm{C}, \quad \max \quad \mathrm{SST}=29.3^{\circ} \mathrm{C} ;$ mean $H_{S}=2.5 \mathrm{~m}$ [SE 0.7], $\min H_{S}=0.7 \mathrm{~m}, \max$ $\left.H_{S}=6.6 \mathrm{~m}\right)$. Therefore, it is unlikely that significant changes detected in coral and algal cover occurred in response to unusual climatic events. Instead, we hypothesize that slight variation in transect placement at NEC-02 between sampling years (CRED, unpubl. data) may be responsible for differences in percentage cover data recorded. No signifi- 
cant differences were found in benthic community composition between years using data from towed-diver surveys, indicating that islandwide benthic assemblages remained stable over the multiyear span of this study.

This study indicates that when analyzed at the island level, benthic functional-group assemblages were spatially homogeneous and temporally static between 2002 and 2006 at Necker Island, and abundances of benthic organisms were similar to those of neighboring reef systems within PMNM. However, slight spatial changes in percentage cover between turf algae, macroalgae, and coral species at select sites emphasize that reef communities do exhibit species-level shifts even in the absence of abiotic or anthropogenic drivers, and that analyses at the functional-group level may be unable to detect these differences. This species-level heterogeneity underscores that coral reefs are complex ecosystems that often transition to alternate states in response to interactions with environmental factors. This shift in reef assemblages may be cryptic and may occur over decades without being observed or analyzed correctly (Bellwood et al. 2004). Therefore, the continued monitoring of algal and macroinvertebrate communities within remote and predominantly pristine reef ecosystems, like those in PMNM, will be critical in the detection of small community changes that, in turn, may indicate the loss of system resilience to large-scale disturbances, such as global climate change or ocean acidification, and signal the onset of phase shifts to alternate states. The availability of robust baseline data, such as those presented in this study, is paramount to allow scientists and managers to document and understand the potential ecological responses to local stressors and large-scale global climate disturbances and will therefore be fundamental for successful coral reef management (Nystrom 2006).

\section{ACKNOWLEDGMENTS}

We thank K. Page-Albins, J. Winsley, E. Looney, C. Squair, and B. DeJoseph for assistance in field collections; C. Wilkinson for analysis of imagery from towed-diver surveys; R. Hoeke for assistance with oceanographic data; T. Acoba for help with towed-diver data matrix and figure creation; A. Toperoff for assistance with graphic design; and the crews of the NOAA ships Townsend Cromwell, Oscar Elton Sette, and Hi ialakai for field support. We also thank P. Ayotte, B. Huntington, E. Looney, R. Santos, and R. Withall for helpful comments during internal review of the manuscript.

\section{Literature Cited}

Abbott, I. A. 1989. Marine algae of the Northwest Hawaiian Islands. Pac. Sci. 43:223233.

1999. The marine red algae of the Hawaiian Islands. Bishop Museum Press, Honolulu, Hawai'i.

Abbott, I. A., and J. M. Huisman. 2004. The marine green and brown algae of the Hawaiian Islands. Bishop Museum Press, Honolulu, Hawai' $i$.

Bellwood, D. R., T. P. Hughes, C. Folke, and M. Nystrom. 2004. Confronting the coral reef crisis. Nature (Lond.) 429:827-833.

Clarke, K. R., and R. N. Gorley. 2006. PRIMER ver. 6: User manual/tutorial. PRIMER-E, Plymouth.

Clarke, K. R., and R. M. Warwick. 2001. Change in marine communities: An approach to statistical analysis and interpretation. 2nd ed. PRIMER-E, Plymouth.

Cleghorn, P. 1988. The settlement and abandonment of two Hawaiian outposts: Nihoa and Necker islands. Bishop Mus. Occas. Pap. 28:35-49.

DeMartini, E. E., G. T. DiNardo, and H. A. Williams. 2003. Temporal changes in population density, fecundity, and egg size in the Hawaiian spiny lobster (Panulirus marginatus) at Necker Bank, Northwestern Hawaiian Islands. Fish. Bull. 101:22-31.

Done, T. J. 1992. Phase shifts in coral reef communities and their ecological significance. Hydrobiologia 247:121-132.

Emory, K. 1928. Archaeology of Nihoa and Necker. Bernice P. Bishop Mus. Bull. 53.

Friedlander, A., G. Aeby, S. Balwani, B. Bowen, R. Brainard, A. Clark, J. Kenyon, J. Maragos, C. Meyer, P. Vroom, and J. Zamzow. 2008. Status of the coral reef 
ecosystems of the Northwest Hawaiian Islands. Pages 263-306 in J. E. Waddell, ed. The state of coral reef ecosystems of the United States and Pacific Freely Associated States: 2008. NOAA Tech. Memo. NOS NCCOS II. NOAA/NCCOS Center for Coastal Monitoring and Assessments Biogeography Team, Silver Spring, Maryland.

Friedlander, A., G. S. Aeby, R. E. Brainard, E. Brown, A. Clark, S. Coles, E. E. DeMartini, S. Dollar, S. Godwin, C. Hunter, P. Jokiel, J. C. Kenyon, R. Kosaki, J. Maragos, P. S. Vroom, W. Walsh, I. Williams, and W. Wiltse. 2004. Status of coral reefs in the Hawaiian archipelago. Pages 411-430 in C. Wilkinson, ed. Status of coral reefs of the world: 2004. Vol. 2. Australian Institute of Marine Science, Townsville, MC, Queensland.

Friedlander, A., G. Aeby, R. Brainard, A. Clark, E. DeMartini, S. Godwin, J. Maragos, J. Kenyon, R. Kosaki, and P. Vroom. 2005. Status of the coral reef ecosystems of the Northwestern Hawaiian Islands. Pages 270-311 in J. E. Waddell, ed. The state of coral reef ecosystems of the United States and Pacific Freely Associated States: 2005. NOAA Tech. Memo. NOS NCCOS II. NOAA/NCCOS Center for Coastal Monitoring and Assessments Biogeography Team, Silver Spring, Maryland.

Friedlander, A. M., and E. E. DeMartini. 2002. Contrasts in density, size, and biomass of reef fishes between the Northwestern and the Main Hawaiian Islands: The effects of fishing down apex predators. Mar. Ecol. Prog. Ser. 230:253-264.

Friedlander, A., K. Keller, W. Wedding, A. Clarke, and M. Monaco, eds. 2009. A marine biogeographic assessment of the Northwestern Hawaiian Islands. NOAA Tech. Memo. NOS NCCOS 4. Prepared by NCCOS's Biogeography Branch in cooperation with the Office of National Marine Sanctuaries Papahānaumokuākea $\mathrm{Ma}$ rine National Monument, Silver Spring, Maryland.

Grigg, R. W. 1983. Community structure, succession and development of coral reefs in Hawai'i. Mar. Ecol. Prog. Ser. 11:1-14.
Grigg, R. W., J.J. Polovina, A. M. Friedlander, and S. O. Rohmann. 2008. Biology of the coral reefs of the Northwestern Hawaiian Islands. Pages 573-594 in B. M. Riegl and R. E. Dodge, eds. Coral reefs of the USA. Springer, Berlin.

Hau, S. 1984. Economic analysis of deep bottomfishing in the Northwestern Hawaiian Islands. Pages 265-282 in The Proceedings of the 2nd Symposium on Resource Investigations in the Northwestern Hawaiian Islands. Vol. 2. Honolulu, Hawai'i.

Heyward, A. J., and A. P. Negri. 1999. Natural inducers for coral larval metamorphosis. Coral Reefs 18:273-279.

Holzwarth, S. R., E. E. DeMartini, B. J. Zgliczynski, and J. L. Laughlin. 2006a. Sharks and jacks in the Northwestern Hawaiian Islands from towed-diver surveys 2000-2003. Atoll Res. Bull. 543:257-279.

Holzwarth, S., B. Zgliczynski, and R. E. Schroeder. 2006b. Spatial distribution of large mobile predators in the Northwestern Hawaiian Islands. Pages 1131-1137 in The Proceedings of the 10th International Coral Reef Symposium, 28 June to 2 July 2004, Okinawa, Japan.

Hughes, T. P. 1994. Catastrophes, phase shifts, and large-scale degradation of a $\mathrm{Ca}$ ribbean coral reef. Science (Washington, D.C.) 265:1547-1551.

Kenyon, J. C., R. E. Brainard, R. K. Hoeke, F. A. Parrish, and C. B. Wilkinson. $2006 a$. Towed-diver surveys, a method for mesoscale spatial assessment of benthic reef habitat: A case study at Midway Atoll in the Hawaiian archipelago. Coastal Manage. 34:339-349.

Kenyon, J. C., P. S. Vroom, K. N. Page, M. J. Dunlap, C. B. Wilkinson, and G. S. Aeby. $2006 \mathrm{~b}$. Community structure of hermatypic corals at French Frigate Shoals, Northwestern Hawaiian Islands: Capacity for resistance and resilience to selective stressors. Pac. Sci. 60:153-175.

Kohler, K. E., and S. M. Gill. 2006. Coral Point Count with Excel extensions (CPCe): A visual basic program for the determination of coral and substrate coverage using random point count methodology. Comput. Geosci. 32:1259-1269. 
Maragos, J., and D. Gulko, eds. 2002. Coral reef ecosystems of the Northwestern $\mathrm{Ha}$ waiian Islands: Interim results emphasizing the 2000 surveys. U.S. Fish and Wildlife Service and Hawai'i Department of Land and Natural Resources, Honolulu.

Maragos, J., J. Kenyon, G. Aeby, P. Vroom, B. Vargas-Angel, R. Brainard, L. Wedding, A. Friedlander, J. Asher, B. Zgliczynski, and D. Siciliano. 2009. Benthic communities. Pages 105-154 in A. Friedlander, K. Keller, L. Wedding, A. Clarke, and M. Monaco, eds. 2009. A marine biogeographic assessment of the Northwestern Hawaiian Islands. NOAA Tech. Memo. NOS NCCOS 84. NCCOS Biogeography Branch and Office of National Marine Sanctuaries Papahānaumokuākea Marine National Monument, Silver Spring, Maryland.

Maragos, J. E., D. C. Potts, G. Aeby, D. Gulko, J. Kenyon, D. Siciliano, and D. VanRavenswaay. 2004. 2000-2002 rapid ecological assessment of corals (Anthozoa) on shallow reefs of the Northwestern Hawaiian Islands. Part 1: Species and distribution. Pac. Sci. 58:211-230.

McManus, J. W., and J. F. Polsenberg. 2004. Coral-algal phase shifts on coral reefs: Ecological and environmental aspects. Prog. Oceanogr. 60:263-279.

Morse, A. N. C., K. Iwao, M. Baba, K. Shimoike, T. Hayashibara, and M. Omori. 1996. An ancient chemosensory mechanism brings new life to coral reefs. Biol. Bull. (Woods Hole) 191:149-154.

Morse, D. E., N. Hooker, A. N. C. Morse, and R. A. Jensen. 1988. Control of larval metamorphosis and recruitment in sympatric agariciid corals. J. Exp. Mar. Biol. Ecol. 116:193-217.

Nystrom, M. 2006. Redundancy and response diversity of functional groups: Implications for the resilience of coral reefs. Ambio 35:30-35.

Parrish, F. A., and R. C. Boland. 2004. Habitat and reef-fish assemblages of banks in the Northwestern Hawaiian Islands. Mar. Biol. (Berl.) 144:1065-1073.

Pooley, S., and K. Kawamoto. 1998. Annual report of the 1995-97 western Pacific lobster fishery. NMFS Southwest Fisheries Science Center, Honolulu, Hawai'i.

Preskitt, L. B., P. S. Vroom, and C. M. Smith. 2004. A rapid ecological assessment (REA) quantitative survey method for benthic algae using photoquadrats with Scuba. Pac. Sci. 58:201-209.

Rohmann, S. O., J. J. Hayes, R. C. Newhall, M. E. Monaco, and R. W. Grigg. 2005. The area of potential shallow-water tropical and subtropical coral reef ecosystems in the United States. Coral Reefs 24:370383.

Vroom, P. S., and C. L. Braun. 2010. What is the benthic composition of a healthy subtropical reef? Baseline species-level percent cover, with an emphasis on reef algae, in the Northwestern Hawaiian Islands. Plos One 5:e9733, doi: 0.1371/journal. pone.0009733.

Vroom, P. S., K. N. Page, J. C. Kenyon, and R. E. Brainard. 2006. Algae-dominated reefs. Am. Sci. 94:429-437.

Vroom, P. S., K. N. Page, K. A. Peyton, and J. K. Kukea-Shultz. 2005. Spatial heterogeneity of benthic community assemblages with an emphasis on reef algae at French Frigate Shoals, Northwestern Hawaiian Islands. Coral Reefs 24:574-581.

Vroom, P. S., and M. A. V. Timmers. 2009. Spatial and temporal comparison of algal biodiversity and benthic cover at Gardner Pinnacles, Northwestern Hawaiian Islands. J. Phycol. 45:337-347. 
